\title{
Purification of the acidic pectate lyase and nucleotide sequence of the corresponding gene (pelA) of Erwinia chrysanthemi strain 3937
}

\author{
Sylvie Favey, ${ }^{1}$ Claude Bourson, ${ }^{2}$ Yves Bertheau, ${ }^{1}$ Alain Kotoujansky ${ }^{1}$ and \\ MARTINE BOCCARA ${ }^{1 *}$ \\ ${ }^{1}$ INRA INA P-G, Laboratoire de Pathologie Végétale, 16 rue Claude Bernard, 75231 Paris cedex 05, France \\ ${ }^{2}$ INSA, Laboratoire de Génétique Moléculaire des Microorganismes, 69621 Villeurbanne, France
}

(Received 1 October 1991; revised 12 November 1991; accepted 18 November 1991)

\begin{abstract}
The pelA gene from Erwinia chrysanthemi strain 3937, which encodes the acidic pectate lyase, PLa, has been sequenced and characterized. The structural gene consists of a 1179 bp open reading frame encoding a polypeptide of $41555 \mathrm{Da}$, which includes an $\mathrm{N}$-terminal signal peptide. The deduced amino acid sequence shows a protein very similar to some PLs already sequenced. Cloning of the pelA gene behind the lacZ promoter of the vector pTZ19R allowed overexpression of PLa into a derivative of strain 3937 deleted of the other pel genes. The mature protein was obtained in milligram amounts from the supernatant of this strain and at homogeneous purity after two purification steps. Its biochemical properties were similar to those of other PLs. Polyclonal antibodies raised against the purified PLa cross-reacted with the basic pectate lyase PLd, but not with PLe. The role of PLa in pathogenicity is discussed.
\end{abstract}

\section{Introduction}

The enterobacterium Erwinia chrysanthemi strain 3937, which causes soft rot disease on its natural host, Saintpaulia ionantha, produces and secretes a battery of depolymerizing enzymes including five isoenzymes of pectate lyase (PL) which can be differentiated by isoelectric focusing (Bertheau et al., 1984). PLs cleave internal glycosidic linkages in pectic polymers by $\beta$-elimination. Five pel genes organized in two clusters encode these five PL activities (Kotoujansky et al., 1985; Reverchon et al., 1986). The genes pelB and pelC are adjacent and encode the two 'neutral' isoenzymes, PLb and PLc. One 'acidic' and two 'alkaline' isoenzymes are produced respectively from the pelA, pelD and pelE genes, and form the second cluster. Each gene is transcribed from its own promoter (Diolez \& Coleno, 1985; Reverchon et al., 1986), and transcription is induced in the presence of polygalacturonate (PGA).

* Author for correspondence. Tel. (1) 43319397 ; fax (1) 43318382.

Abbreviations: PGA, polygalacturonate; PL, pectate lyase; PLa, acidic pectate lyase.

The nucleotide sequence data reported in this paper have been submitted to GenBank and have been assigned the accession number M77808.
Despite strong similarity between the PLa and PLe amino acid sequences (Tamaki et al., 1988), PLa shows differences from other secreted PLs of E. chrysanthemi. PLa has an acidic isoelectric point, has poor maceration activity on potato tuber (Garibaldi \& Bateman, 1971; Barras et al., 1987; Tamaki et al., 1988), and its gene, pelA, is hardly induced by PGA (Reverchon et al., 1986). Nevertheless, PLa is essential for full pathogenicity of $E$. chrysanthemi 3937 on Saintpaulia plants (Boccara et al., 1988). Furthermore, no cross-reactivity was observed between PLa and others PLs with polyclonal (Pupillo et al., 1976) or monoclonal antibodies (Vergnet-Ballas et al., 1986; Y. Bertheau and others, unpublished).

No antibody against PLa has so far been obtained. To prepare an antiserum which recognizes PLa, the purification of the PLa isoenzyme was undertaken and is presented in this paper. To otain PLa in its mature state, we chose to purify it from the culture medium of an $E$. chrysanthemi strain overproducing PLa.

\section{Methods}

Bacterial strains, plasmids, media and growth conditions. The bacterial strains and plasmids used in this study are shown in Table 1. Eschericia coli strains were grown in Luria broth medium (L medium) (Miller, 1972) at $37^{\circ} \mathrm{C}$. All Erwinia chrysanthemi strains used in this study derived from the wild-type strain 3937 . E. chrysanthemi strains were 
Table 1. Bacterial strains, plasmids and bacteriophage

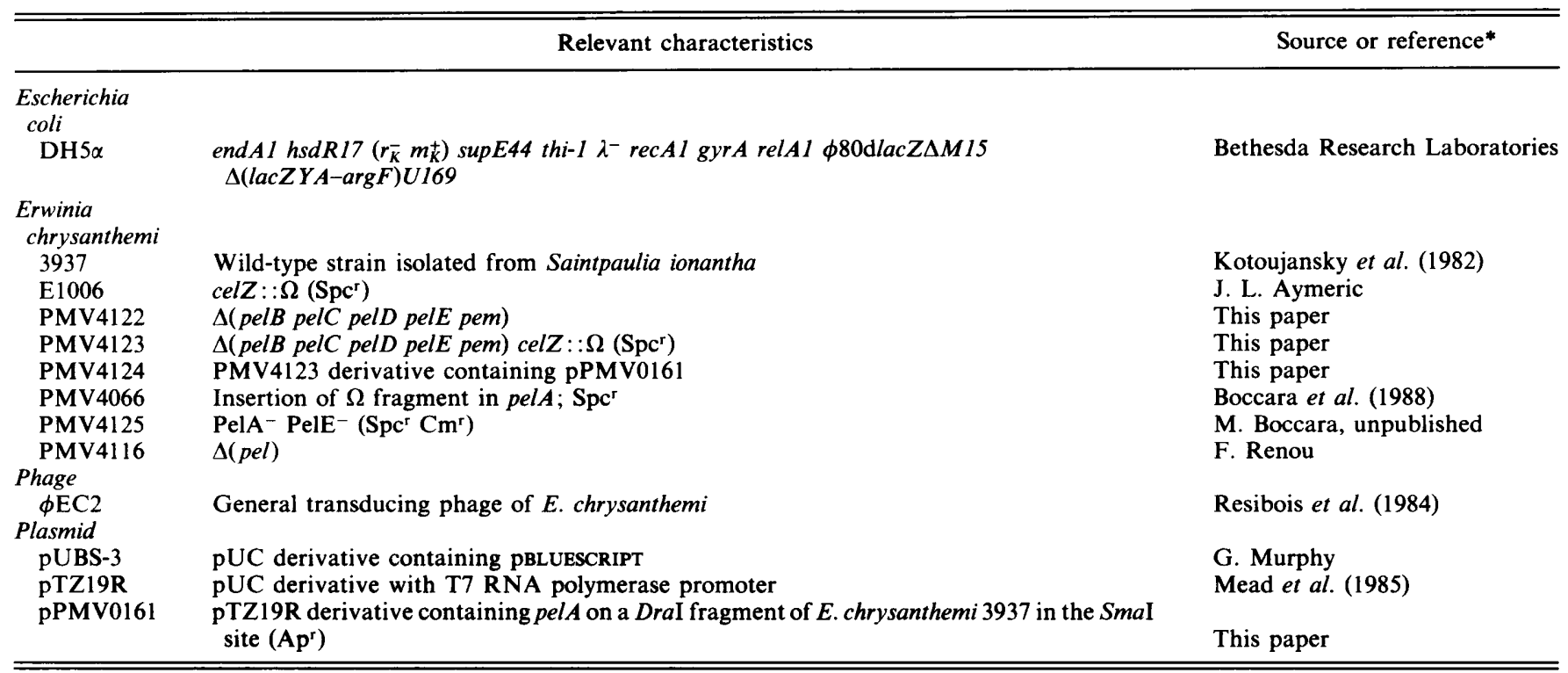

* J. L. Aymeric, LCB, Marseille, France; F. Renou, INA, Paris, France; G. Murphy, IPS, Norwich, UK.

grown at $30^{\circ} \mathrm{C}$ in $\mathrm{L}$ medium or in PL-inducing medium (per litre: $\mathrm{KH}_{2} \mathrm{PO}_{4}, 3 \mathrm{~g} ; \mathrm{Na}_{2} \mathrm{HPO}_{4}, 0.5 \mathrm{~g} ; \mathrm{MgSO}_{4} .7 \mathrm{H}, \mathrm{O}, 0.2 \mathrm{~g} ;\left(\mathrm{NH}_{4}\right) \mathrm{SO}_{4}, 3 \mathrm{~g}$; Casamino acids (Difco), $5 \mathrm{~g}$; polygalacturonic acid (Sigma), $5 \mathrm{~g}$; adjusted to $\mathrm{pH}$ 7) (Bertheau et al., 1984). PL-producing bacteria were screened on PGT agar, comprising M9 agar medium (Miller, 1972) supplemented with $5 \mathrm{~g}$ glycerol, $1 \mathrm{~g}$ yeast extract and $5 \mathrm{~g}$ sodium PGA $1^{-1}$. Antibiotics were used at the following concentrations: ampicillin $50 \mu \mathrm{g} \mathrm{ml}^{-1}$, chloramphenicol $20 \mu \mathrm{g} \mathrm{ml}^{-1}$ and spectinomycin $25 \mu \mathrm{g} \mathrm{ml}^{-1}$.

Preparation of phage lysates. Transduction with phage $\phi \mathrm{EC} 2$ was performed according to Resibois et al. (1982).

DNA analysis. Large-scale preparations of plasmid DNAs were made from clear lysates followed by two centrifugations in a caesium chloride/ethidium bromide density gradient (Maniatis et al., 1982). Mini-scale preparations of plasmid DNAs were made from Escherichia coli cells by the rapid boiling method of Holmes \& Quigley (1981). After restriction, the DNA was electrophoresed in $0.8 \%$ agarose gels in Tris/borate buffer (Maniatis et al., 1982). Restriction enzymes and T4 DNA ligase (BRL) were used according to the supplier's recommendations.

DNA sequencing. DNA sequencing was performed by the dideoxy chain-termination method of Sanger et al. (1977) using the Sequenase kit (United States Biochemical Corporation). The pelA-containing fragment was digested by the restriction enzymes Sau3A, TaqI, AluI and HpaII. The resulting fragments were cloned in Escherichia coli DH5 $\alpha$ into the plasmid pUBS-3 and used for sequencing. Migration was carried out on gels $80 \mathrm{~cm}$ in length $(6 \%, \mathrm{w} / \mathrm{v}$, acrylamide and $460 \mathrm{~g}$ urea $\left.1^{-1}\right)$. Analysis of the sequence was carried out using programs developed by the University of Wisconsin Genetics Computer Group (Devereux et al., 1984).

Cup-plate assays. Activities of PLs, proteases, cellulases and pectin methylesterase were tested by the cup-plate method as described by Bertheau et al. (1984).

$P L$ assays. PL assays were performed on supernatants of cells grown to late exponential phase in PL-inducing medium. PL activity was determined by the release from PGA (Sigma) of unsaturated products that absorb at $235 \mathrm{~nm}$ (Moran et al., 1968) in 0.1 M-Tris buffer pH 8.6, $5 \times 10^{-4} \mathrm{M}-\mathrm{CaCl}_{2}$. One unit of PL activity was defined as $1 \mu \mathrm{mol}$ unsaturated products liberated $\min ^{-1}(\mathrm{mg} \text { bacterial dry weight })^{-1}$.

Preparation of concentrated supernatants. Strain PMV4124 was grown in PL-inducing medium at $30^{\circ} \mathrm{C}$ to $\mathrm{OD}_{600}=2$. The culture was centrifuged at $6000 \mathrm{~g}$ and then filtered successively through $8 \mu \mathrm{m}$, $0.8 \mu \mathrm{m}, 0.45 \mu \mathrm{m}$ and $0.22 \mu \mathrm{m}$ filters (Millipore) and concentrated against polyethylene glycol (Carbowax 20M, Touzard and Matignon) in dialysis tubing. After concentration, the bags were extensively

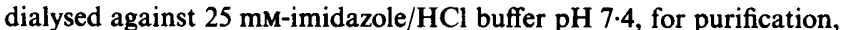
or $100 \mathrm{~mm}$-Tris/ $\mathrm{HCl}$ buffer $\mathrm{pH} \mathrm{8.6,} \mathrm{for} \mathrm{analytical} \mathrm{purposes.} \mathrm{A} \mathrm{final}$ concentration of 100 -fold was achieved. Protein concentration was measured according to Bradford (1976) with bovine serum albumin (Boehringer Mannheim) as a standard. This crude supernatant was stored at $4{ }^{\circ} \mathrm{C}$.

Purification of PLa. Step 1: chromatofocusing. Two millilitres ( $2 \mathrm{mg}$ protein) of the 100 -fold-concentrated crude extract in $25 \mathrm{mM}$ imidazole $/ \mathrm{HCl}$ buffer $\mathrm{pH} 7.4$ was loaded onto an HPLC chromatofocusing column (Mono P HR5/20, Pharmacia) equilibrated in the same buffer for $20 \mathrm{~min}$. The adsorbed protein fractions were eluted after $18 \mathrm{~min}$ washing, using $55 \mathrm{ml}$ polybuffer 7-4 (Pharmacia) diluted 10 -fold and adjusted to $\mathrm{pH} 3 \cdot 5$. The column was then regenerated with

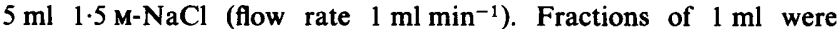
collected and PL activity tested by the cup-plate assay. PL-active fractions were pooled, concentrated against polyethylene glycol and dialysed against $100 \mathrm{~mm}$-Tris/ $\mathrm{HCl}$ buffer $\mathrm{pH} 8 \cdot 6$.

Step 2: hydrophobic interaction chromatography. The fractions mentioned above were added to an equal volume of $3.4 \mathrm{M}-\left(\mathrm{NH}_{4}\right)_{2} \mathrm{SO}_{4}$ and loaded onto a hydrophobic interaction HPLC column (Phenyl Superose HR5/5, Pharmacia), equilibrated with $1.7 \mathrm{M}-\left(\mathrm{NH}_{4}\right)_{2} \mathrm{SO}_{4}$ in $50 \mathrm{~mm}$-Tris $/ \mathrm{HCl} \mathrm{pH} 8.6$. Elution was done with a decreasing linear gradient of $\left(\mathrm{NH}_{4}\right)_{2} \mathrm{SO}_{4}$ in the same buffer (flow rate $0.5 \mathrm{ml} \mathrm{min}{ }^{-1}$ ). The fractions exhibiting PL activity were pooled, further concentrated and dialysed using Centricon 10 microconcentrators (Amicon), and stored at $4{ }^{\circ} \mathrm{C}$. 
Isoelectric focusing (IEF). PL isoenzymes were analysed in the supernatant of stationary-phase bacteria grown in PL-inducing medium. Fifteen microlitres of each fraction were layered on a thin polyacrylamide gel and electrofocusing was performed in a $\mathrm{pH}$ gradient from 3 to 10 (Pharmacia). PL activities were assessed directly on the gel by an overlay technique according to Bertheau et al. (1984).

Polyacrylamide gel electrophoresis. Electrophoresis under denaturing conditions (SDS-PAGE) was performed according to Laemmli (1970), with a $2 \%(w / v)$ stacking gel and a $12 \%(w / v)$ running gel, using the Mini-Protean II dual slab cell system (Bio-Rad). Gels were fixed and proteins stained according to the silver nitrate method of Merril et al. (1981). To enhance subsequent renaturation of PL, bovine serum albumin (Boehringer Mannheim) at $20 \mu \mathrm{g} \mathrm{ml}^{-1}$ was incorporated in the resolving gel when the gels were to be stained for enzyme activity (Lacks \& Springhorn, 1980). The gels were then incubated in several changes of $10 \mathrm{~mm}$-Tris/ $\mathrm{HCl} \mathrm{pH} 7.5$ for $1 \mathrm{~h}$ before being assayed by the overlay technique of Bertheau et al. (1984).

Origin and production of antibodies. Polyclonal antibodies were produced in two rabbits by a modification of the method described by Vaitukaitis (1981). The first immunization consisted of 10 intradermal multipoint injections of $100 \mu \mathrm{l}(2.5 \mu \mathrm{g}$ purified enzyme). Then, on a further four occasions, at $20 \mathrm{~d}$ intervals, one subcutaneous injection $(1 \mathrm{ml}, 25 \mu \mathrm{g}$ of purified enzyme) was performed. Serum samples were taken just before each injection.

Immunoblotting. Proteins were electrotransferred from SDS-PAGE or IEF gels to nitrocellulose membranes (BA 85, 0.45 $\mu \mathrm{m}$, Schleicher and Schüll) according to Towbin et al. (1979). Proteins bound to the nitrocellulose membrane were stained with $0.5 \%(w / v)$ Ponceau red $S$ Electran (BDH) in $5 \%(w / v)$ trichloracetic acid and afterwards washed in water. Immunological detection of proteins on nitrocellulose was slightly modified from Towbin et al. (1979). Incubations and rinsing were performed at room temperature. PLa was detected by incubation with the appropriate antisera, followed by goat anti-rabbit IgG alkaline phosphatase conjugate (Biosys). Blots were developed at $37^{\circ} \mathrm{C}$ in a mixture $(1: 1, \mathrm{v} / \mathrm{v})$ of $0.4 \%(\mathrm{w} / \mathrm{v})$ fast red TR salt (Sigma) in $0.2 \mathrm{M}-$ Tris/ $/ \mathrm{HCl}$ buffer pH 8 and a $6 \%(\mathrm{w} / \mathrm{v})$ solution of naphthol As-Mx (Sigma) in distilled water.

\section{Results}

\section{Sequence of the pelA gene}

To achieve overexpression of PLa, sequencing of the pelA gene of strain 3937 was first undertaken. The pelA gene was shown to be included in a $1.6 \mathrm{~kb}$ DraI fragment, as PLa activity was detected in Escherichia coli strains harbouring PPMV0161. This fragment was sequenced. The data, summarized in Fig. 1, revealed a single long open reading frame of $1179 \mathrm{bp}$, which corresponds to the PLa preprotein. It was not possible to assign putative promoter sequences with assurance, since computer searches failed to disclose any typical $E$. coli promoter sequences $5^{\prime}$ to the coding region. However, several putative weak promoter sequences were present. Nuclease S1 mapping experiments have so far been unsuccessful as pelA RNA was found to be very unstable (C. Bourson, unpublished). Upstream from the pelA gene, we identified two putative $\mathrm{KdgR}$-binding sites.
The $\mathrm{KdgR}$ protein regulates many genes involved in the pectin degradation pathway (Condemine \& RobertBaudouy, 1987), and a consensus sequence for $\mathrm{KdgR}$ binding showing the typical symmetry of operator sites has been determined (Reverchon et al., 1989; Condemine \& Robert-Baudouy, 1991). Furthermore, an AT-rich region, as described for other sequenced pel genes (Reverchon et al., 1989; Tamaki et al., 1988), was also observed in the $5^{\prime}$ untranslated end of the pelA gene. This region could be of importance for the regulation of the pel genes. A GC-rich palindromic sequence, followed by a $T$ repeat, occurred after the translational stop codon of pelA (TAA). This sequence is typical of rho-independent transcription-termination sites (Von Hippel et al., 1984). All the PL genes of E. chrysanthemi so far sequenced possess a TAA stop codon and a rhoindependent transcription-termination site (Schoedel \& Collmer, 1986; Tamaki et al., 1988; Reverchon et al., 1989).

Upstream of the initiation codon we observed a typical Shine-Dalgarno sequence. The deduced amino acid sequence of the pelA gene corresponded to a polypeptide of 393 amino acids, with a calculated molecular mass of $41555 \mathrm{Da}$, and included a typical $\mathrm{N}$-terminal signal sequence. The cleavage site of this signal peptide was predicted to be between the two alanine residues at nucleotide positions 336 and 337 (Fig. 1). This was confirmed by determining the sequence of the 17 first amino acids of the purified mature protein. The mature PLa protein contains 361 amino acids, and has a calculated molecular mass of $38412 \mathrm{Da}$ and a calculated pI of 5.2. The deduced amino acid sequence of $E$. chrysanthemi 3937 PLa was compared with the published sequences of PLs from E. chrysanthemi strains EC16, B374 and 3937. Our sequence has considerable similarity (about $60 \%$ ) with the PLd and PLe of these three strains and $90 \%$ similarity with the PLa of strain EC16. The similarity is greatest in the central part of the protein.

\section{Construction of a strain overproducing $P L a$}

To obtain a strain producing solely PLa, a mutant of strain 3937 deficient in the production of the PLb, PLc, PLd and PLe isoenzymes was constructed by using marker exchange-eviction mutagenesis with the nptsacB-sacR cartridge as described by Ried \& Collmer (1988). The clone PMV4122, which had suffered a $6 \mathrm{~kb}$ deletion covering the pelB and pelC genes and a deletion of $6.7 \mathrm{~kb}$ which removed the pelD, pelE and pem genes, was selected for PLa production (F. Renou \& M. Boccara, unpublished).

The endoglucanase EgZ, secreted by $E$. chrysanthemi 3937, has a pI similar to that of PLa (Boyer et al., 1987). To eliminate $\mathrm{EgZ}$ protein, the $\mathrm{celZ}:: \Omega$ mutation of strain 
Dra

30

50

70

90

110

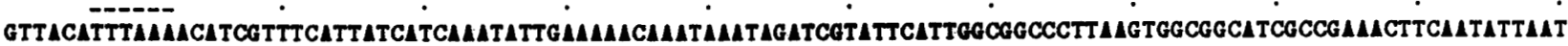

$\begin{array}{llll}\text { KdgR binding site } & 150 & 170 & \text { ClaI }\end{array}$

AATAALCATt

$230 \quad 250 \quad 370 \quad 30$

AGGATTT ÄT

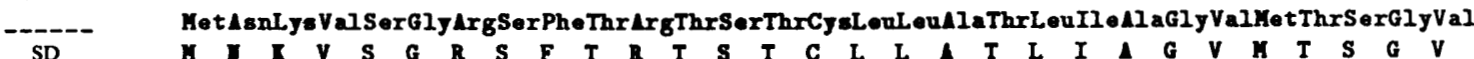

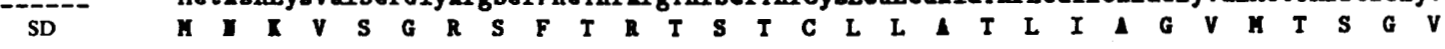

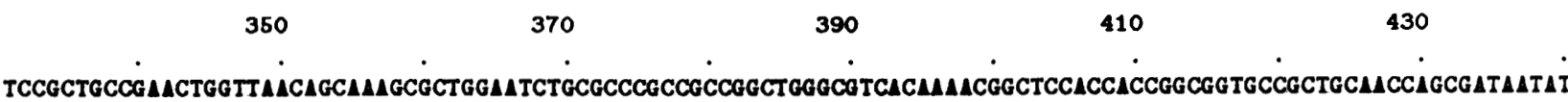

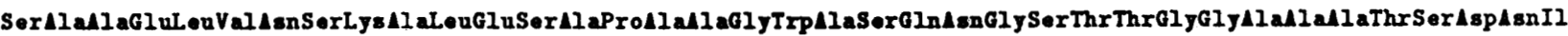

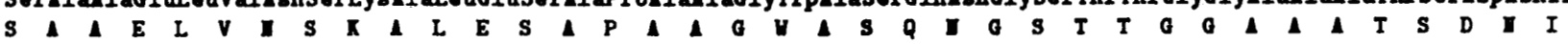

$\begin{array}{lllll}460 & E c o R I & 490 & 610 & 630\end{array}$

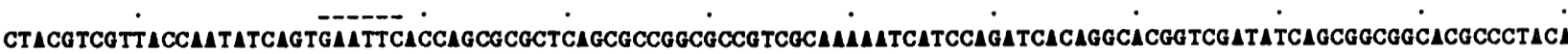

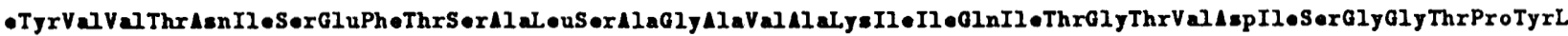

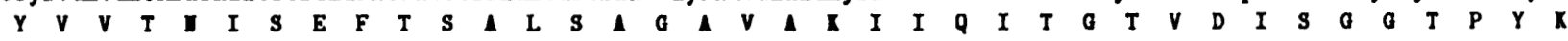
570
590
610
630
650

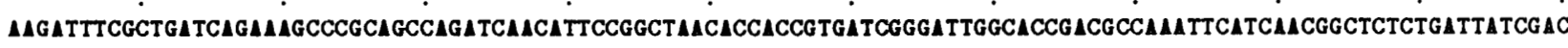

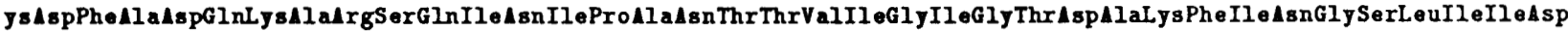

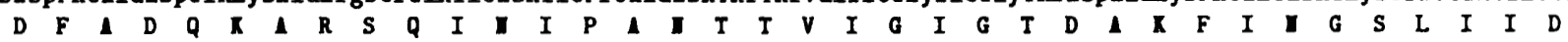

$\begin{array}{lllllll}K \text { KnI } 670 & 690 & 710 & 730 & 750\end{array}$

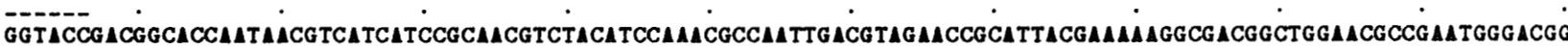

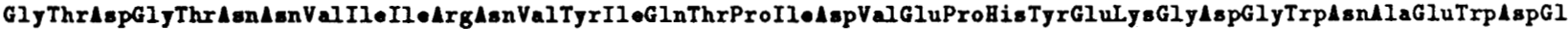

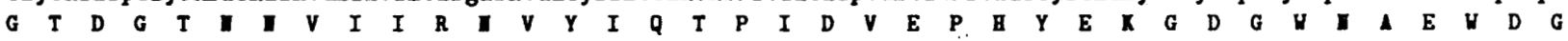

$\begin{array}{lllll}790 & \text { Sall } & 830 & 850 & 870\end{array}$

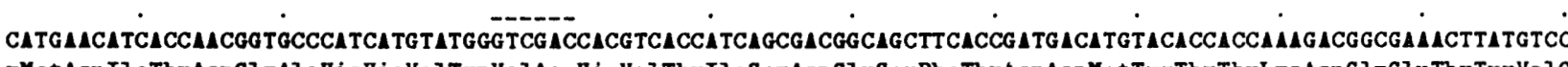
yHetAsnIleThrAsnGlJAlaHisHisValTrpValAspHisValThrIleSerAspGlySerPheThrAspAspMetTyrThrThrLysAspGlyGluThrTyrValG

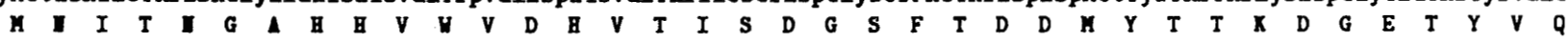

$\begin{array}{llllll}890 & 910 & 930 & 950 & 970 & 990\end{array}$

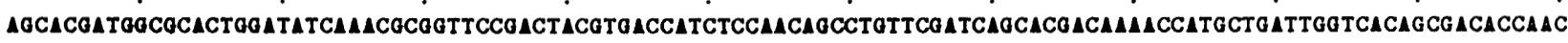

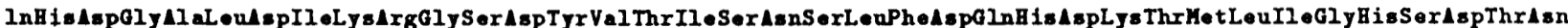

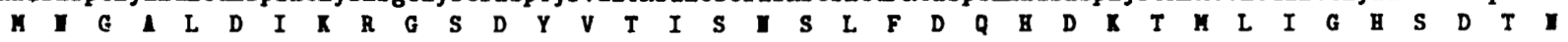

$\begin{array}{lllll}1010 & 1030 & 1060 & 1070 & 1090\end{array}$

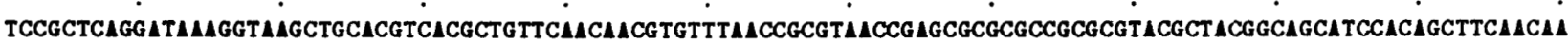

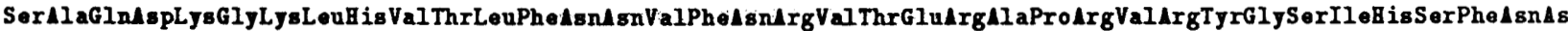

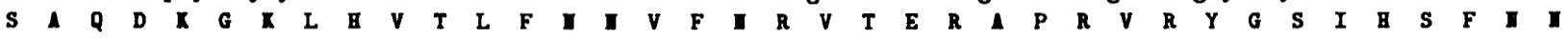

1110

Accl 1150

1170

1190

1210

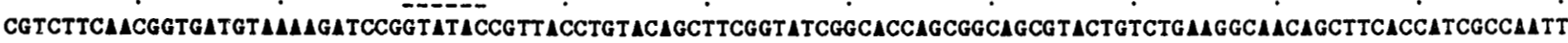

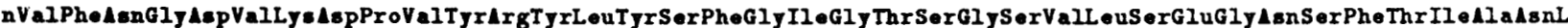

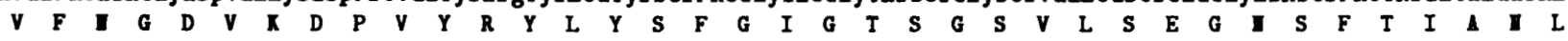
1230 1250

1270

1290

1310

TGAGCGCAGCAMGCGTGCAMGTTGTGAMAMATCAACGGCTCCATTTTCTCCGACALTGTTCCGTCCTGATGGCAGCGCCGCCGATCTGTCCGGTTGTGGTTTC euSerAlaSerLyeAl aCyeLysValVallysL ysPheAsnglySerIlePheSerAsplsnglySerValLeuAsnglySerAlaAlaAspLeuSerGlyCysGlyPhe

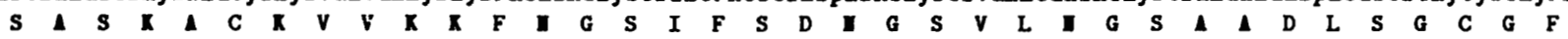


1330

1350

1370

1390

1410

1430

AGCGCTTACACCAGCGCGATTCCTTACGTTTACGCCGTTCAGCCGATGACTACCGACTGGCGCATCCATTACGGACCACGCAGGTTCAGGCAAGTGTATTTCCCGT

SerAlaTyrThrSerAlaIleProTyrValTyrAlaValginProhetThrThrgluLeuAlaGlnSerIleThrAspHisAlaglySerGlyLysLeu

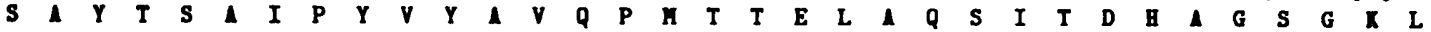

$\begin{array}{lllll}1450 & 1470 & 1490 & 1510 & 1530\end{array}$

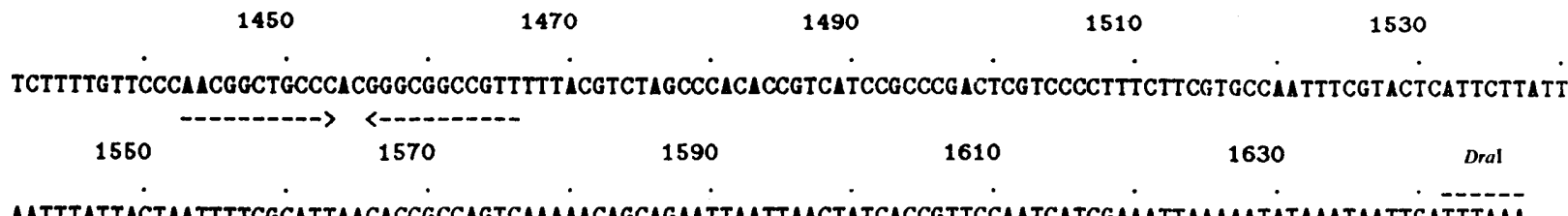

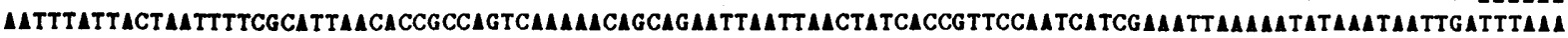

Fig. 1. Nucleotide sequence of the $1.6 \mathrm{~kb}$ Dral fragment containing the pelA gene of $E$. chrysanthemi strain 3937 . The deduced amino acid sequence of PLa is shown and selected restriction sites are specified. The putative Shine-Dalgarno sequence (SD) and KdgRbinding sites are underlined. The potential rho-independent termination sites are indicated by facing arrows representing the inverted repeat of $G+C$-rich dyad symmetry preceding the poly(T) sequence. The downward arrow indicates the signal sequence cleavage site of PLa.

E1006 (J. L. Aymeric, unpublished) was introduced into strain PMV4122 by transduction with phage $\phi \mathrm{EC} 2$. A $\mathrm{Spc}^{\mathrm{r}} \mathrm{CelZ}^{-}$transductant was obtained and called PMV4123.

Finally, the $1.6 \mathrm{~kb}$ DraI fragment containing the pelA gene cloned in the SmaI site of pTZ19R (Mead et al., 1985) was introduced into strain PMV-4123. When the lac $Z$ promoter was present upstream of the pel $A$ gene, the PLa activity in PL-inducing medium was 15 -fold higher than when the DraI fragment was in the other orientation. One clone, PMV4124, was retained. The protein profiles after SDS-PAGE of supernatants of strains 3937, PMV4122 and PMV4124 grown in PLinducing medium (see Fig. $3 a$ ) showed that PLa, as identified by its activity, represented the major protein in the culture medium of strain PMV4124 whereas it was hardly visible in the other two strains.

\section{Purification of PLa}

Titration curves in polyacrylamide gels showed that PLa had a strong charge variation around its isoelectric point (data not shown). Thus we chose chromatofocusing for the first step of purification.

After chromatofocusing, PL activity appeared in the 42-44 min fractions (Fig. 2a). These fractions were pooled, concentrated and dialysed for the next purification step. No protease, cellulase or pectin methylesterase activities were found in these fractions. Silvernitrate-stained IEF and SDS-PAGE gels showed purity of PLa after this step (Fig. $3 a, b$ ). However, the PLa-containing fractions were contaminated with ampholines present in the polybuffer used for elution.

To remove the ampholines, hydrophobic interaction chromatography was used. The ampholines are not fixed onto the hydrophobic gel, whereas the adsorbed PLa activity eluted at the end of the decreasing $\left(\mathrm{NH}_{4}\right)_{2} \mathrm{SO}_{4}$ gradient (Fig. 2b). A single protein peak with PLa activity was obtained.
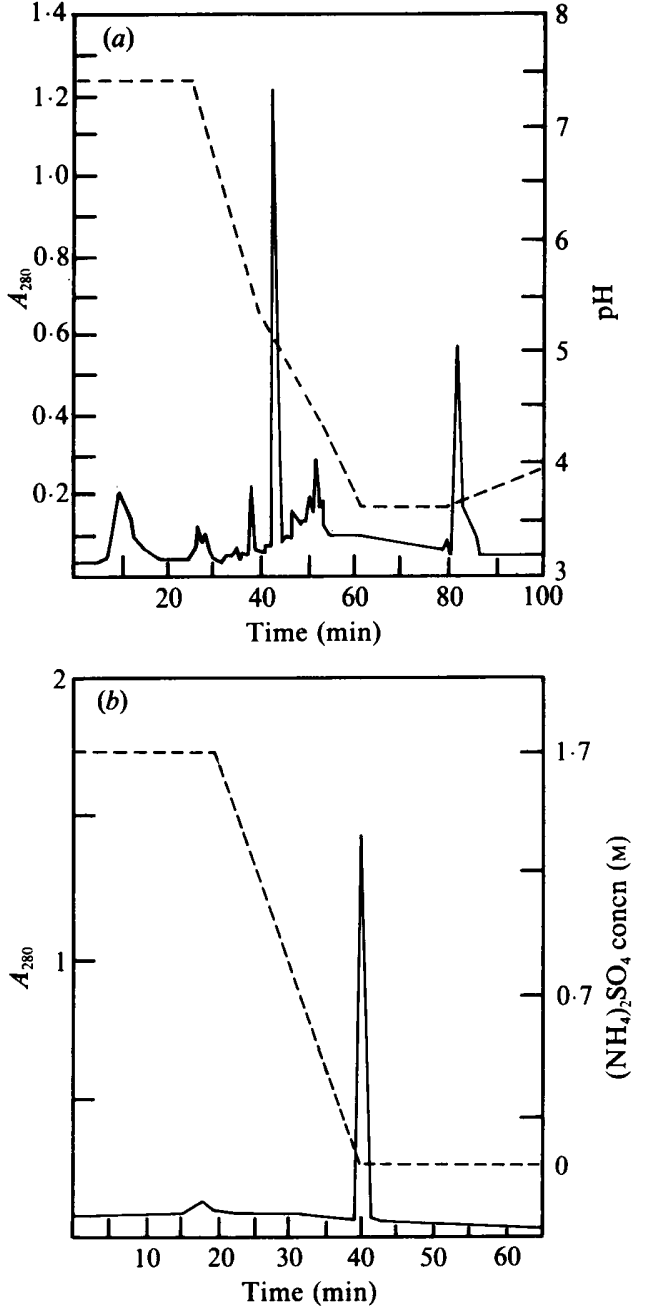

Fig. 2. Chromatography profiles of the purification of PLa. (a) Chromatofocusing profile (Mono P HR5/20) of concentrated PMV4124 culture supernatant. PLa activity is present in the $42-44 \mathrm{~min}$ fractions. - , $A_{280} ;---$, pH. (b) Hydrophobic interaction chromatography profile. PLa was separated from ampholines on a Phenyl Superose HR5/5 column. PLa activity was found in the 39-42 min fractions. - $-\mathrm{A}_{280} ;---,\left(\mathrm{NH}_{4}\right)_{2} \mathrm{SO}_{4}$ concentration. 


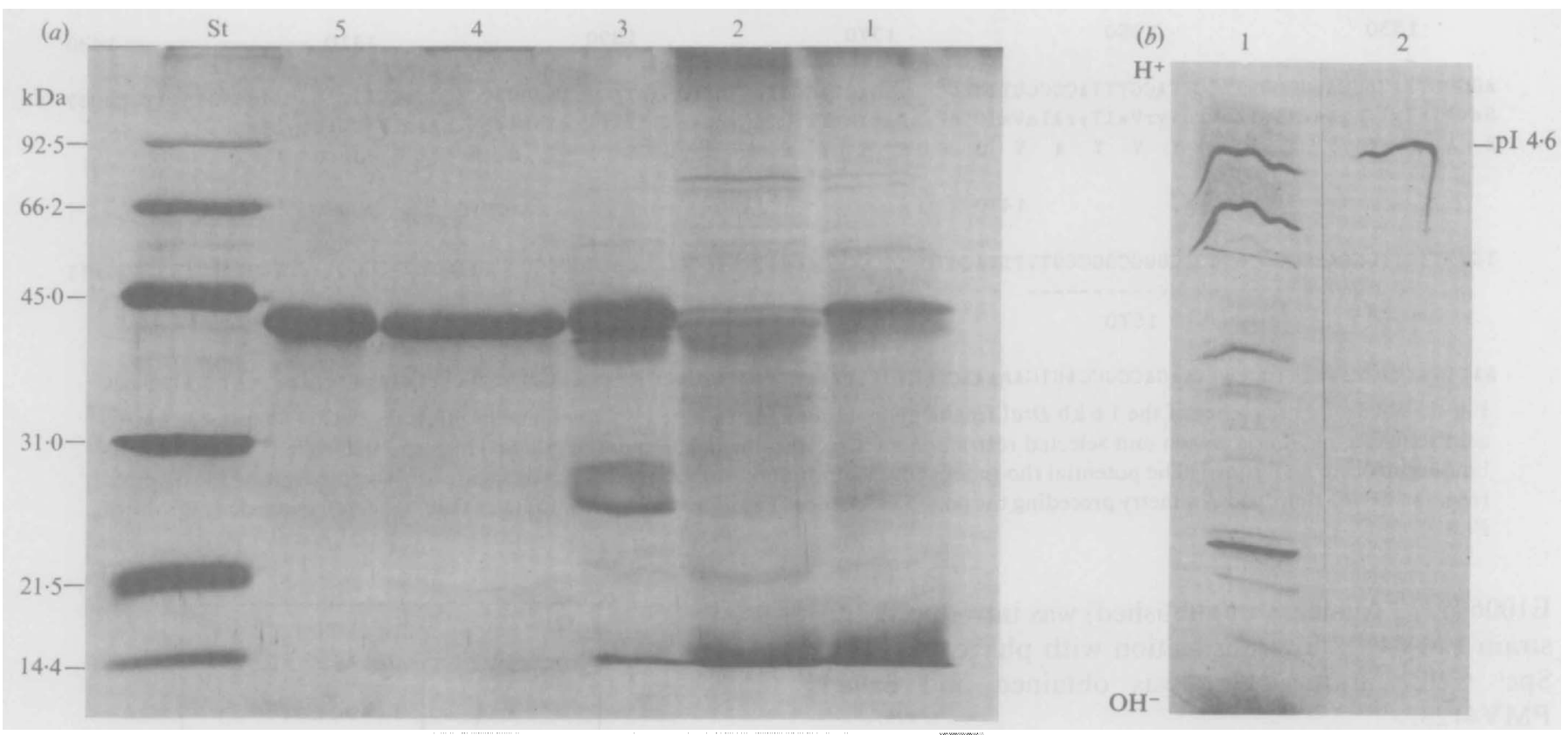

Fig. 3. Silver-stained SDS-PAGE and IEF gels of samples at different stages of the purification. (a) SDS-PAGE (12\% acrylamide; $3 \mu \mathrm{g}$ protein loaded). St, molecular mass standards (Bio-Rad); lane 1, concentrated supernatant from strain 3937; lane 2, concentrated supernatant from strain PMV4122; lane 3, concentrated supernatant from strain PMV4124; lane 4, pooled $42-44$ min fractions from the chromatofocusing; lane 5, PLa peak (40.2 min) from the hydrophobic interaction chromatography. (b) IEF polyacrylamide gel ( $\mathrm{pH}$ range 3-10, $5 \mu$ g protein loaded). Lane 1, concentrated supernatant from strain PMV4124; lane 2, PLa peak from the hydrophobic interaction chromatography. The wavy appearance of PLa in IEF gels has often been observed for acidic proteins (Y. Bertheau, unpublished).

Table 2. Recovery of PLa activity and protein during the purification procedure

\begin{tabular}{lcccccc}
\hline \hline \multicolumn{1}{c}{ Step } & $\begin{array}{c}\text { Volume } \\
(\mathrm{ml})\end{array}$ & $\begin{array}{c}\text { Total } \\
\text { protein } \\
(\mathrm{mg})\end{array}$ & $\begin{array}{c}\text { Total } \\
\text { activity } \\
(\mathrm{U})\end{array}$ & $\begin{array}{c}\text { Specific } \\
\text { activity } \\
\left(\mathrm{U} \mathrm{mg} \mathrm{m}^{-1}\right)\end{array}$ & $\begin{array}{c}\text { Purification } \\
(\text {-fold })\end{array}$ & $\begin{array}{c}\text { PL activity } \\
\text { recovered } \\
(\%)\end{array}$ \\
\hline Supernatant & 1000 & 27.5 & 28500 & 1040 & $1 \cdot 0$ & 100 \\
100-fold concentrate & 10 & $12 \cdot 8$ & 20270 & 1580 & $1 \cdot 52$ & 71 \\
Mono P HR5/20 & 2 & 1.66 & 3370 & 2030 & 1.95 & 12 \\
Phenyl Superose HR5/5 & 0.44 & 1.35 & 3100 & 2300 & $2 \cdot 21$ & 10.9 \\
\hline \hline
\end{tabular}

Purity of the protein was checked with silver-nitratestained SDS-PAGE and IEF gels (Fig. $3 a, b$ ). Using this two-step purification procedure, PLa was obtained at homogenous purity but with only $11 \%$ recovery of PLa activity (Table 2 ).

\section{Biochemical properties of the PLa}

Using a purified preparation of the mature PLa protein isolated from the supernatant fraction of strain PMV4124, the N-terminal residue was shown to be alanine. This classical cleavage site presumably accounts for the fact that PLa is efficiently exported to the periplasm of Escherichia coli cells (Reverchon et al., 1985). The purified enzyme migrated in SDS-PAGE with an apparent molecular mass of $44 \mathrm{kDa}$. DNA sequence data gave a molecular mass of $39 \mathrm{kDa}$ for the mature protein. This discrepancy was also observed for PLe and PLa of E. chrysanthemi EC16 (Tamaki et al., 1988). The behaviour of PLe was previously suspected to be due to its relatively high $\mathrm{pI}$; however, this cannot be applied to PLa. A pI of 4.6 was consistently found in equilibrated IEF gels (Fig. $3 b$ ), this being different from the value of 5.2 obtained from the DNA sequence and chromatofocusing data. IEF gels and chromatofocusing were performed at different temperatures, at 4 and $20^{\circ} \mathrm{C}$, respectively, which might explain the observed difference in pI values.

An increase in pectin esterification (more than $20 \%$ of galacturonic acid residues methoxylated) led to less 


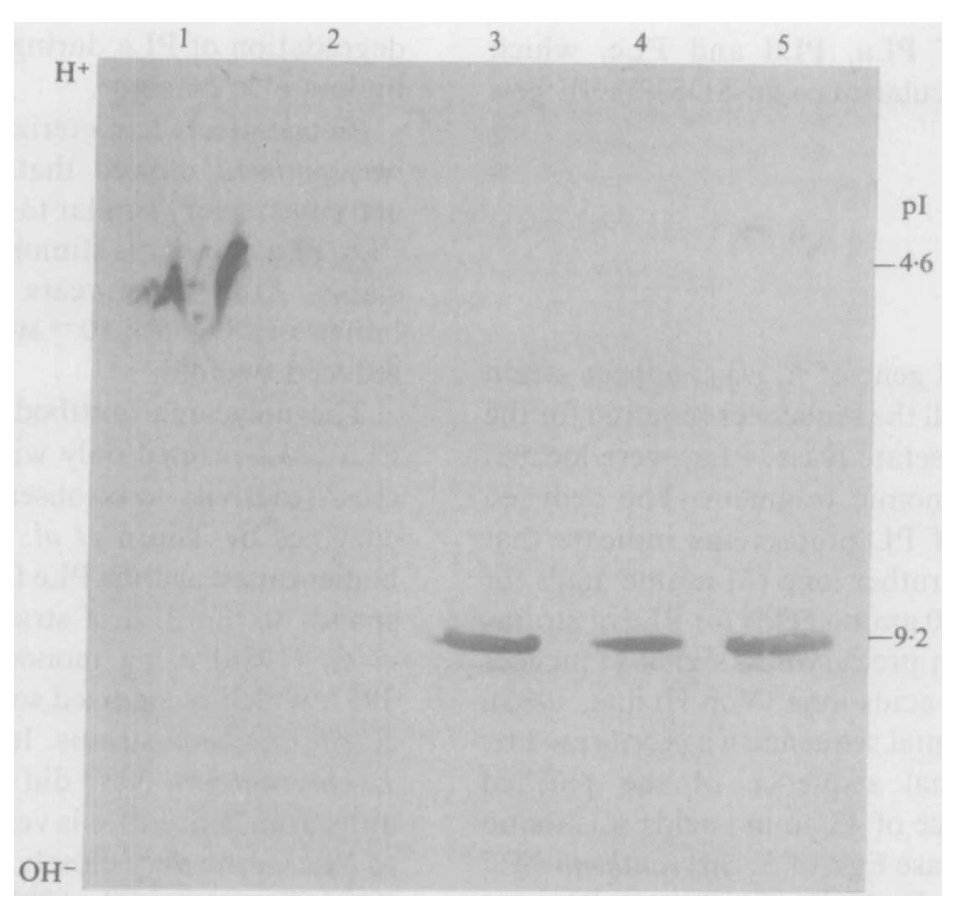

Fig. 4. Immunoblots, with a 1000-fold serum dilution, of purified PLa and concentrated culture supernatant from different strains of $E$. chrysanthemi after isoelectrofocusing (1 $\mu$ g protein). Lane 1, purified PLa from strain PMV4124; lane 2, PMV4122; lane 3, PMV4125; lane 4, PMV4066; lane 5, 3937.

efficient degradation of the substrate by PLa (data not shown). This result was expected, since PLs cleave internal glycosidic linkages by $\beta$-elimination after demethylation of the pectic polymer by pectin methylesterase. PLa caused a rapid decrease in the viscosity of PGA as measured in an Ostwald viscosimeter with a concomitant production of unsaturated products (a viscosity decrease of $50 \%$ corresponds to an $A_{235}$ less than $0 \cdot 1$ ), suggesting random cleavage of the substrate (data not shown). PLa was most active at $\mathrm{pH} 8.6$ and $50^{\circ} \mathrm{C}$ in $0.1 \mathrm{M}$-Tris/ $\mathrm{HCl}, 5 \times 10^{-4} \mathrm{M}^{-\mathrm{CaCl}_{2}}$. The activity was significantly stimulated by $\mathrm{Ca}^{2+}\left(5 \times 10^{-4} \mathrm{M}-\mathrm{Ca}^{2+}\right.$ increased the activity 15 -fold compared to the control without $\mathrm{Ca}^{2+}$ ), a property which is shared by bacterial and fungal PLs. No other monovalent and divalent cations tested, including $\mathrm{Na}^{+}, \mathrm{K}^{+}, \mathrm{Mg}^{2+}$ and $\mathrm{Mn}^{2+}$ (as chloride salts), stimulated PLa activity. Addition of $0.1 \mathrm{~mm}$-EDTA or $0.5 \mathrm{~mm}-\mathrm{Hg}^{2+}$ completely inhibited PLa activity. The initial velocity for the reaction allowing the formation of unsaturated oligogalacturonides from PGA, at different concentrations of PGA, in $0.1 \mathrm{M}$-Tris/ $\mathrm{HCl}$ buffer $\mathrm{pH} 8.6,5 \times 10^{-4} \mathrm{M}-\mathrm{CaCl}_{2}$ and at $30^{\circ} \mathrm{C}$, was determined by spectrophotometric assay. From a Lineweaver-Burk plot of the data, the apparent $K_{\mathrm{m}}$ and $V_{\max }$ were estimated to be $0.43 \mathrm{mg} \mathrm{ml}^{-1}$ and $483 \mathrm{U} \mathrm{ml}^{-1}$, respectively. These results are similar to those obtained with PLb and PLc of E. chrysanthemi strain CUCPB1237 (Schoedel \& Collmer, 1986).

\section{Characterization of antibodies raised against PLa}

Polyclonal antibodies were raised against purified PLa. Immunoblotting after IEF of concentrated supernatant ( $1 \mu \mathrm{g}$ protein) of strain 3937 revealed two reacting bands at a 1000-fold serum dilution. One band corresponded to PLa (pI 4.6), the other showed a pI value of 9.2 , corresponding to the $\mathrm{pI}$ of the PLd isoenzyme (Fig. 4). Even at a 200 -fold dilution of the serum, no crossreactivity was observed with PLe, although this PL was shown to have high similarity with PLd (Van Gijsegem, 1989). The band corresponding to PLa was not visible when $1 \mu \mathrm{g}$ total protein was loaded, but a band corresponding to PLd was detected (not shown). The specificity of our antibodies was confirmed by using concentrated supernatant of strains PMV4066 and PMV4125, which are pelA and pelA pelE mutants respectively (Fig. 4). In addition, no reacting band was detected with strain PMV4116, a $\mathrm{Pel}^{-}$mutant (data not shown). After SDS-PAGE immunoblotting, only one immunoreactive protein band of $44 \mathrm{kDa}$ was detected in concentrated supernatant of strain 3937 at a 200 -fold serum dilution (not shown). The size of this protein 
corresponded to that of PLa, PLd and PLe, which exhibited the same molecular mass in SDS-PAGE gels (Fig. 3a).

\section{Discussion}

The sequence of the pelA gene of $E$. chrysanthemi strain 3937 demonstrated that all the sequences required for the synthesis of the acidic pectate lyase, PLa, were located within a $1.6 \mathrm{~kb}$ DraI genomic fragment. The deduced amino acid sequences of PL preproteins indicate that their signal peptides are rather long ( 31 amino acids for PLa of strain 3937, and 30 amino acids for PLe of strains 3937 and $\mathrm{EC16}$ ), since in prokaryotes, signal sequences are usually 21-23 amino acids long (Von Heijne, 1985). The length of the PLa signal sequence was confirmed by analysing the $\mathrm{N}$-terminal sequence of the purified protein. A signal sequence of 43 amino acids was found for the major endoglucanase $\mathrm{EgZ}$ of E. chrysanthemi 3937 (Guiseppi et al., 1988). Endoglucanases and PLs are secreted by the same mechanism (Andro et al., 1984), thus a longer signal sequence could play a role in the secretion of these proteins. However, the PLb preprotein possesses a signal sequence of 22 amino acids and PLb is also secreted (Keen \& Tamaki, 1986).

In strain 3937 , PLa activity represented about $3 \%$ of the total PL activity, the pelA gene being transcribed at a low level compared to the other pel genes (Reverchon \& Robert-Baudouy, 1987). So, to obtain an E., chrysanthemi strain which overexpresses PLa, the $1.6 \mathrm{~kb}$ DraI fragment was cloned behind the lac $Z$ promoter and used to transform strain PMV4123, which produces only PLa. PLa was the major extracellular protein of the resulting strain PMV4124, which allowed purification of the protein in large amount. To obtain a PL in significant quantities, other groups (Keen \& Tamaki, 1986; Schoedel \& Collmer, 1986) have previously cloned a pel gene on a high-copy-number plasmid in an Escherichia coli strain, PL then being purified from the periplasm. The mechanism by which proteins cross the inner membrane seems similar in the two bacteria, but in $E$. coli, PLs are not secreted. Although proteins obtained from the two bacterial species have very similar $\mathrm{pI}$ values and molecular masses, one cannot exclude slight modification of the protein after the secretion step, and we therefore chose to purify PLa from the culture supernatant of Erwinia chrysanthemi strain PMV4124. In this strain, PLa was the major secreted protein, which might explain the final purification rate of $2 \cdot 21$-fold (Table 2 ). After the first purification step, $83 \%$ of PL activity and $87 \%$ of proteins were lost. As PLa is the major supernatant protein (Fig. 2), this loss could be due to degradation of PLa during its purification, for example by loss of a cofactor.

Biochemical characterization of purified PLa from $E$. chrysanthemi showed that optimal conditions for PLa activity are very similar to those of other $E$. chrysanthemi PLs. PLa activity is stimulated by $\mathrm{Ca}^{2+}$ ions, and is very stable. After three years at $4{ }^{\circ} \mathrm{C}$ in $100 \mathrm{mM}-\mathrm{Tris} / \mathrm{HCl}$

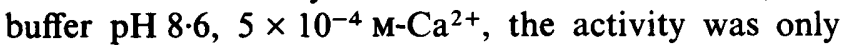
reduced twofold.

The polyclonal antibodies that we obtained against PLa cross-reacted only with PLd (Fig. 4). Similarly no cross-reactivity was observed between these two isoenzymes by Thurn et al. (1987) using polyclonal antibodies raised against PLe from strain EC16, which corresponds to the PLd of strain 3937, or by Vergnet-Ballas et al. (1986) using monoclonal antibodies from strain 3937, which recognized solely PLd and PLe of all tested $E$. chrysanthemi strains. It is surprising that the PLe of E. chrysanthemi 3937 did not react with our polyclonal antiserum, since PLd is very similar at the sequence level to PLe in the very closely related $E$. chrysanthemi strain B374 (Boccara et al., 1991; Van Gijsegem et al., 1989), and since the three proteins belong to the same family, according to the homologies observed by Hinton et al. (1989). The cross-reactivity observed could be explained by comparing polypeptide sequences, the PLa protein of E. chrysanthemi 3937 being slightly more similar to PLd than PLe of strain B374. Alternatively, the threedimensional structure of PLe could be sufficiently different from those of PLd and PLa to explain these results.

Immunolocalization of PLs secreted by the bacteria in Saintpaulia plants infected by $E$. chrysanthemi 3937 has been performed using monoclonal antibodies respectively specific for PLb and PLc (Temsah et al., 1991). The results showed that PLb and PLc were preferentially located in the middle lamella and cell junction, whereas preliminary results indicated that PLd and PLe were preferentially located in the cell wall area close to the plasmalemma (M. Temsah, personal communication). Does PLa act differently in planta from the other PLs? Study of the localization of PLa in planta, using antibodies, could illuminate the importance of this isoenzyme in pathogenesis. However, monoclonal antibodies seem necessary, since our polyclonal antiserum cross-reacted with PLd. Alternately, a pelD mutant could be used.

Different studies (Hinton et al., 1989; Tamaki et al., 1988; Van Gijsegem, 1989; A. Darrasse \& Y. Bertheau, unpublished) have shown that the PLa, PLd, PLe family, determined by sequence homology or by PCR amplification, is not present in Erwinia carotovora strains. Analysis of the PL profile of a large number of $E$. chrysanthemi strains of different geographical origins has 
been performed (Boccara et al., 1991). PLa was present in most of the strains but not in a very homogeneous group of strains isolated in temperate countries. Studies of PL synthesis of strain 3937 at different temperatures showed an eightfold decrease at $37^{\circ} \mathrm{C}$ compared to $30^{\circ} \mathrm{C}$ (data not shown). However, strain PMV4122, which secreted only PLa, exhibited the same activity at both temperatures. Taken together, these results might suggest that PLa could contribute to the ability of $E$. chrysanthemi to cause symptoms at supraoptimal temperatures.

The PLa isoenzyme of $E$. chrysanthemi $\mathrm{EC1} 16$ is a much less efficient macerating factor of plant tissue than PLe (Garibaldi \& Bateman, 1971; Tamaki et al., 1988). It was suggested that the difference in $\mathrm{pI}$ between these two proteins may explain this observation. However, results obtained by Tamaki et al. (1988) for several recombinant pelA/pelE genes suggest that other factors, in addition to the low pI value of PLa, may contribute to its poor macerating efficiency. Despite the poor ability of PLa to macerate potato tubers, Boccara et al. (1988) showed that PLa was essential for full pathogenicity of $E$. chrysanthemi 3937 on Saintpaulia plants. PLs with little plantmacerating ability on potato tubers and low pI values, similar to PLa, have also been described for the nonplant-pathogenic bacteria Klebsiella pneumoniae and Yersinia pseudotuberculosis (Chatterjee et al., 1979; Manulis et al., 1988). The fact that these bacteria were often encountered in the soil raises the possibility that the acidic PLs may have alternative, as yet unknown, physiological functions for the survival of these bacteria in the soil.

Like all the genes of $E$. chrysanthemi involved in pectin degradation that have been identified, pelA is regulated by $\mathrm{KdgR}$ (C. Bourson, unpublished). Analysis of the pelA nucleotide sequence has shown the presence of two putative KdgR-binding sites, one $17 \mathrm{bp}$ long and the other $15 \mathrm{bp}$ long, similar to the KdgR-box consensus sequence A(AT)AAAA(AT)GAAA ....TGTTTCATT(AT)T(AT)T determined by Condemine \& RobertBaudouy (1991). In PL-inducing medium, pelA expression was shown to be very weak compared with that of the other pel genes. However, preliminary results suggested that pelA is induced by total soluble plant extracts (C. Bourson and others, unpublished). Pupillo et al. (1976) have already shown that unlike the other PLs, the induction of PLa was stimulated in planta. Studies are in progress to determine whether the conditions for PLa induction differ from those for other PLs; these should give information on the possible role of PLa in planta.

We thank C. Kunz for help during PLa purification and A. S. Dumond (Laboratoire de Microbiologie, Institut Gustave Roussy,
Villejuif) for help in preparing antibodies. We are grateful to F. Renou for providing strain PMV4116 and to G. Murphy for the plasmid pUBS-3. The N-terminal protein sequencing was performed in the Laboratoire d'Étude des Proteines by J. C. Huet, INRA Versailles (Dir. J. C. Pernollet). This work was financially supported by Institut National de la Recherche Agronomique, Agence Nationale de Valorisation de la Recherche and by the Commission of the European Communities (contract BAP-0190-B). S. Favey was a fellow from Ministère de la Recherche et de l'Enseignement Supérieur.

\section{References}

Andro, T., Chambost, J. P., Kotoujansky, A., Cattaneo, J., BertheaU, Y., Barras, F., VAN Giusegem, F. \& Coleno, A. (1984). Mutants of Erwinia chrysanthemi defective in secretion of pectinase and cellulase. Journal of Bacteriology 160, 1199-1203.

Barras, F., ThuRN, K. K. \& ChatterJee, A. K. (1987). Resolution of four pectate lyase structural genes of Erwinia chrysanthemi (EC16) and characterization of the enzymes produced in Escherichia coli. Molecular and General Genetics 209, 319-325.

Bertheau, Y., Madgidi-Hervan, E., Kotoujansky, A., NguyenTHE, C., ANDRo, T. \& Coleno, A. (1984). Detection of depolymerase isoenzymes after electrophoresis or electrofocusing, or in titration curves. Analytical Biochemistry 139, 383-389.

Boccara, M., Diolez, A., Rouve, M. \& Kotoujansky, A. (1988). The role of individual pectate lyase of Erwinia chrysanthemi strain 3937 in pathogenicity on Saintpaulia plants. Physiological and Molecular Plant Pathology 33, 95-104.

Boccara, M., Vedel, R., Lalo, D., Lebrun, M. H. \& Lafay, J. F. (1991). Genetic diversity and host range in strains of Erwinia chrysanthemi. Molecular Plant-Microbe Interactions 4, 293-299.

Boyer, M. H., Cami, B., Kotoujansky, A., Chambost, J. P., Frixon, C. \& CATtaneo, J. (1987). Isolation of the gene encoding the major endoglucanase of Erwinia chrysanthemi. Homology between cel genes of two strains of Erwinia chrysanthemi. FEMS Microbiology Letters 41, 351-356.

BRADFoRD, M. M. (1976). A rapid and sensitive method for the quantitation of microgram quantities of protein utilizing the principle of protein-dye binding. Analytical Biochemistry 72, 248-254.

Chatterjee, A. K., Buchanan, G. E., Behrens, M. K. \& Stark, M. P. (1979). Synthesis and excretion of polygalacturonic acid transeliminase in Erwinia, Yersinia and Klebsiella species. Canadian Journal of Microbiology 25, 94-102.

CONDEMINE, G. \& RoberT-BAUdouY, J. (1987). Tn5 insertion in $k d g r$, a regulatory gene of the polygalacturonate pathway in E. chrysanthemi. FEMS Microbiology Letters 42, 39-46.

CONDEMINE, G. \& ROBERT-BAudoy, J. (1991). Analysis of an Erwinia chrysanthemi gene cluster involved in pectin degradation. Molecular Microbiology 5, 2191-2202.

DevereuX, J., Hazberli, P. \& Smithies, O. (1984). A comprehensive set of sequence analysis programs for the VAX. Nucleic Acids Research 12, 387-395.

Diolez, A. \& Coleno, A. (1985). Mu-lac insertion-directed mutagenesis in a pectate lyase gene of Erwinia chrysanthemi. Journal of Bacteriology 163, 913-917.

Garibaldi, A. \& Bateman, D. F. (1971). Pectic enzymes produced by Erwinia chrysanthemi and their effects on plant tissue. Physiological Plant Pathology 1, 25-40.

Guiseppi, A., Cami, B., Aymeric, J. L., Ball, G. \& Creuzet, N. (1988). Homology between endoglucanase $Z$ of Erwinia chrysanthemi and endoglucanases of Bacillus subtilis and alkalophilic bacillus. Molecular Microbiology 2, 159-164.

Hinton, J. C. D., Sidebotham, J. M., Gill, D. R. \& Salmond, G. P. C. (1989). Extracellular and periplasmic isoenzymes of pectate lyase from Erwinia carotovora subspecies carotovora belong to different gene families. Molecular Microbiology 3, 1785-1795. 
Holmes, D. S. \& Quigley, M. (1981). A rapid boiling method for the preparation of bacterial plasmids. Analytical Biochemistry 114, 193-197.

KEEN, N. T. \& TAMAKI, S. (1986). Structure of two pectate lyase genes from Erwinia chrysanthemi EC16 and their high-level expression in Escherichia coli. Journal of Bacteriology 168, 595-606.

Kotoujansky, A., LematTRE, M. \& BoistaRd, P. (1982). Utilization of a thermosensitive episome bearing transposon $\mathrm{Tn} 10$ to isolate $\mathrm{Hfr}$ donor strains of Erwinia carotovora subsp. chrysanthemi. Journal of Bacteriology 150, 122-131.

Kotoujansky, A., Diolez, A., Boccara, M., Bertheau, Y., Andro, T. \& COLENO, A. (1985). Molecular cloning of Erwinia chrysanthemi pectinase and cellulase structural genes. EMBO Journal 4, 781-785.

LACKS, S. A. \& SPRINGHORN, S. S. (1980). Renaturation of enzymes after polyacrylamide gel electrophoresis in the presence of sodium dodecyl sulfate. Journal of Biological Chemistry 255, 7467-7473.

LAEMMLI, U. K. (1970). Cleavage of structural proteins during the assembly of the head of bacteriophage T4. Nature, London 227 , 680-685.

Maniatis, T., Fritsch, E. F. \& Sambrook, J. (1982). Molecular Cloning. A Laboratory Manual. Cold Spring Harbor, NY: Cold Spring Harbor Laboratory.

Manulis, S., Kobayashi, D. Y. \& KeEN, N. T. (1988). Molecular cloning and sequencing of a pectate lyase gene from Yersinia pseudotuberculosis. Journal of Bacteriology 170, 1825-1830.

MEAD, D. A., SKopura, E. S. \& KeMPeR, B. (1985). Single stranded DNA promoter plasmids for engineering mutant RNA's and protein: synthesis of a stretched parathyroid hormone. Nucleic Acids Research 13, 1103-1108.

Merril, C. R., Goldman, D., Sedman, S. A. \& Ebert, M. H. (1981). Ultrasensitive stain for proteins in polyacrylamide gels shows regional variation in cerebrospinal fluid proteins. Science 27, 1437-1438.

MilLeR, J. H. (1972). Experiments in Molecular Genetics. Cold Spring Harbor, NY: Cold Spring Harbor Laboratory.

Moran, F., Nasumo, S. \& StarR, M. P. (1968). Extracellular and intracellular polygalacturonic acid trans-eliminases of Erwinio carotovora. Archives of Biochemistry and Biophysics 123, 298-306.

Pupillo, P., Mazzucchi, U. \& Pierini, G. (1976). Pectic lyase isozymes produced by Erwinia chrysanthemi Burkh. et al. in polypectate broth or in Dieffenbachia leaves. Physiological Plant Pathology 9, 113-120.

Resibois, A., Colet, M. \& Toussaint, A. (1982). Localisation of miniMu in its replication intermediates. EMBO Journal 1, 965-969.

REVERCHON, S. \& ROBERT-BAudOUY, J. (1987). Regulation of expression of pectate lyase genes pelA, pelD, and pelE in Erwinia chrysanthemi. Journal of Bacteriology 169, 2417-2423.

Reverchon, S., HugouvieuX-Cotte-Pattat, N. \& RobertBAUDOUY, J. (1985). Cloning of genes encoding pectolytic enzymes from a genomic library of the phytopathogenic bacterium, Erwinia chrysanthemi. Gene 35, 121-130.

Reverchon, S., Van Gisjegem, F., Rouve, M, Kotoujansky, A. \& ROBERT-BAUDOUY, J. (1986). Organisation of a pectate lyase gene family in Erwinia chrysanthemi. Gene 49, 215-224.

Reverchon, S., Huang, Y., Bourson, C. \& Robert-Baudouy, J. (1989). Nucleotide sequences of the Erwinia chrysanthemi ogl and pelE genes negatively regulated by the $k d g r$ gene product. Gene 85 , $125-134$.

Ried, J. F. \& Collmer, A. (1988). Construction and characterization of an Erwinia chrysanthemi mutant with directed deletions in all of the pectate lyase structural genes. Molecular Plant-Microbe Interactions 1, 32-38.

SANGer, F., Nicklen, S. \& Coulson, A. R. (1977). DNA sequencing with chain-terminating inhibitors. Proceedings of the National Academy of Sciences of the United States of America 74, 54635467.

SCHOEDEL, C. \& Collmer, A. (1986). Evidence of homology between the pectate lyase-encoding pelB and pelC genes in Erwinia chrysanthemi. Journal of Bacteriology 167, 117-123.

Tamaki, S. J., Gold, S., Robeson, M., Manulis, S. \& Keen, N. T. (1988). Structure and organization of the pel genes from Erwinia chrysanthemi EC16. Journal of Bacteriology 170, 3468-3478.

Temsah, M., Bertheau, B. \& Vian, B. (1991). Pectate-lyase fixation and pectate disorganization visualized by immunocytochemistry in Saintpaulia ionantha infected by Erwinia chrysanthemi. Cell Biology International Reports 15, 611-620.

Thurn, K. K., Barras, F., Kegoya-Yoshino, Y. \& Chatterjee, A. K (1987). Pectate lyase of Erwinia chrysanthemi: PelE-like polypeptides and pelE homologous sequences in strains isolated from different plants. Physiological and Molecular Plant Pathology 31, 429-439.

TowBin, H., Staehelin, T. \& GoRdon, J. (1979). Electrophoretic transfer of proteins from polyacrylamide gels to nitrocellulose sheets: procedure and some applications. Proceedings of the National Academy of Sciences of the United States of America 76, 4350-4354.

VaItUKaItis, J. L. (1981). Production of antisera with small doses of immunogen: multiple intradermal injections. Methods in Enzymology 73, 46-52.

VAN GIJSEGEM, F. (1989). Relationship between the pel genes of the pelADE cluster of Erwinia chrysanthemi strain B374. Molecular Microbiology 3, 1415-1424.

Vergnet-Ballas, C., Bertheau, Y. \& Grosglaude, J. (1986). Production and potential uses of monoclonal antibodies to pectate lyases of Erwinia chrysanthemi. Symbiosis 2, 367-372.

VoN HeiJNe, G. (1985). Signal sequences. The limits of variation. Journal of Molecular Biology 184, 99-105.

Von Hippel, P. H., Bear, D. G., Morgan, W. D. \& MCSwiggen, J. A. (1984). Protein-nucleic acid interactions in transcription: a molecular analysis. Annual Review of Biochemistry 53, 389-446. 